\title{
PROFESSOR JOHN WILLIAM CALDER
}

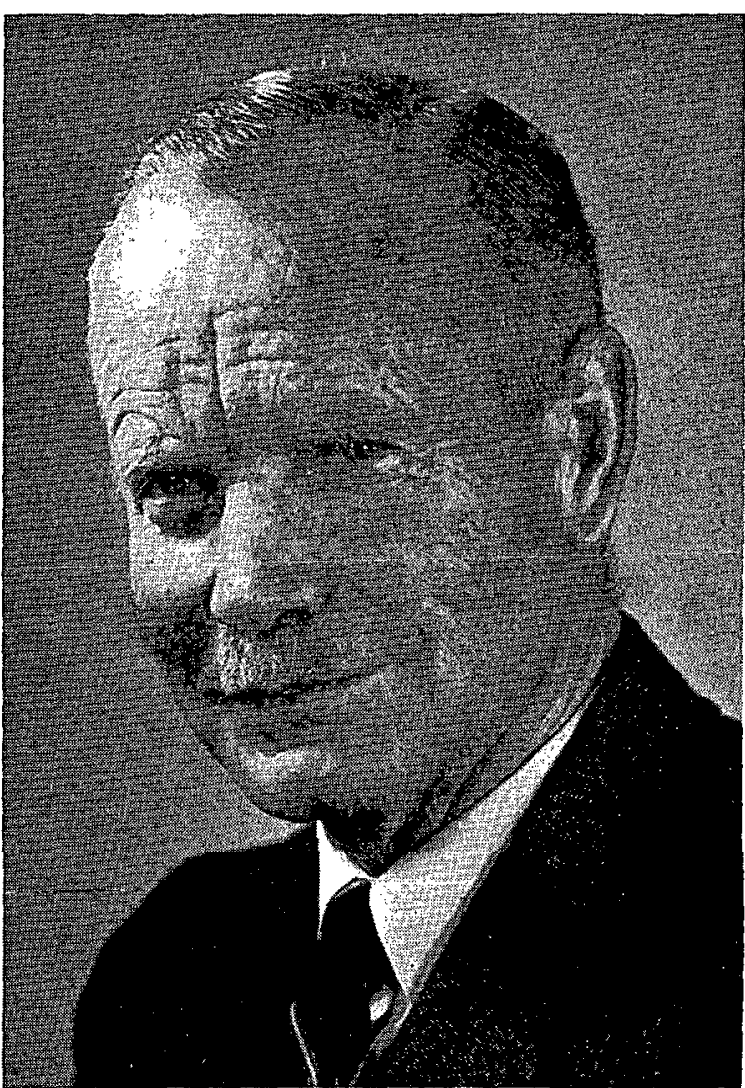

THE three sons of Andrew Calder each attained great distinction which would have given him, a good and humble man, feelings of immense family pride. The youngest son, Malcolm, completed an Ll,B. degree, but made a career in the RNZAF in both war and peace. He retired with the rank -of Wing Commander, Chief of the Air Staff, C.B. and C.B.E. The second son, Roy, at his untimely death in 1948 was Director, Crop Research Division, DSIR, and had by then contributed greatly to agronomy and the breeding of crop plants for New Zealand conditions, When they learned of the death on November 16, 1972, in his 71 st year, of the eldest son, Jack Calder, a host of people students, colleagues, farmers, businessmen, must have paused in 
their activity and meditated on how that outstanding and unique personality had impinged on their own lives. It is considered within that community which is Lincoln College-present and past - that no other life and service there was more comprehensively appreciated.

In his membership of professional societies, Jack Calder gave his chief support to the New Zealand Grassland Association, joining in its second year (1933). He was a frequent committee member, contributed original papers at four early conferences (1933-36 inclusive) and the address of his Presidential year is recorded in the Proceedings of $1956 \rightarrow$ the year in which many delegates to the International Grassland Conference at Palmerston North later reassembled at Lincoln for the New Zealand Association's meeting. It is appropriate, therefore, to record J. W. Calder's biography in these Proceedings.

He left the .Temuka District High School, South Canterbury, in 1917 at the age of 16 and commenced work as a bank clerk. Meanwhile his headmaster, confident of his top boy's potential, had applied successfully on Jack's behalf for one of the newly established, agricultural bursaries of the Education Department and the young man set off for Lincoln in a confusion of wonder and trepidation.

He completed the three-year diploma of agriculture (1918-20) but L. J. Wild, then one of the only four lecturers on the College staff, counselled him to enter upon the fledgling B.Agr. - "the back-to-front" degree course with agriculture completed first, science at the end. Thus in 1921, after a period when he rode a bike to and from Lincoln (14 miles each day) to attend lectures, he obtained a place at College House, Canterbury University College, and completed the requirements of the science papers. His bursary required him to prepare himself for teaching, hence the year 1922 was spent at Christchurch Training College but through some formula he was enabled to apply successfully for a position at the then Canterbury Agricultural College and in 1923 went into residence at Lincoln as the "House-master", with a miscellany of lecturing duties ranging from mathematics to practical demonstration on the steam traction engine. He married Kathleen Free in 1925 , by which year he was advancing in scientific work as the associate of the illustrious Dr F. W. Hilgendorf. Some of this work (1) was incorporated in a thesis for the M.Sc. degree awarded in 1927.

He served Lincoln College as a staff member continuously for 35 years with progressive advancement to the Professorship of 
Agricultural Botany (1955). He was Assistant Director to E. R. Hudson from 1936 and on three occasions had responsibility as Acting Director of the institution. In 1949 he was the frst staff member travelling overseas within the newly established refresher leave programme, and in 1955 was recipient of the Bledisloe Medal, the College's premier award to a former student whose contribution to New Zealand or this country's interests is deemed of outstanding merit. (The Medal had also been awarded (posthumously) to his brother, Roy.) He retired, somewhat unexpectedly, in 1958 and was happily occupied for nearly 6 years at Bicester, Oxfordshire, United Kingdom, as consultant to Twyford Seeds Limited, eventually returning in 1964 to live in retirement in the Lincoln township.

\section{SCIENTIFIC WORK}

There was great mutual benefit in the happy association of Hilgendorf and Calder. Some of the latter's Masterate thesis was published (2) by the N.Z. Institute, describing with 14 line drawings a condition of carpellody in wheat and demonstrated during three season's field work to be inherited as a recessive. He had also been spending time in the South Island tussock and mountain country, developing his association with pioneer botanists and ecologists.

In 1932 he was co-author with Dr L. Cockayne of a paper in the Journal of Ecology (3) which compared vegetation at the top of Arthurs Pass with the condition Cockayne had reported in 1899. Calder himself studied 274 indigenous species in this work and discussed ten changes in the plant associations. His own photographs, for those times, were also of distinct merit. In 1969, when living in retirement and with the collaboration of Dr P. Wardle, Botany Division, DSIR, a third report (22) was made on the successions. An ecological study of this kind spanning 70 years is 'regarded as being almost unique. By this time (1932) he was an enthusiastic field man and, having commenced strain studies at the College on pasture plants, he included his collection of indigenous Danthonia in the plots. A paper (4) was then published in 1937 by the Linnean Society reviewing the systematics of the group and discussing from his own efforts the value of cytology in differentiating 13 New Zealand species. Two basic chromosome groups were described and it was proposed that three forms previously considered as varieties of $D$. semiannualaris should be raised to specific rank. These three papers 
were each of high scientific merit, the work being done in what in these days would be regarded as difficult physical and personal circumstances. He might have then become introvert and specialized in one or other of the facets of plant breeding or ecology to which he had now contributed. The job at Lincoln, however, and the nature of the College as a place for training agriculturalists, called for general practitioners. They had to be teachers first, make research contributions if possible, and also take the message through extension to the community. Jack Calder was possibly the most all-round useful staff member the College has had and in succeeding years became pivotal in every facet of academic affairs, farm management, student life and public relations.

As Hilgendorf's extra hand and complementary brain from 1924, they developed excellently managed plots concerned with selection and hybridization of crop and pasture plants. This work preceded the establishment of the Department of Scientific and Industrial Research. Hilgendorf ultimately concentrated on wheat and was the influence behind the establishment of the Wheat Research Institute which he eventually directed. Calder had charge of the grass and clover programme from 1932 but also showed, in passing, the benefits of potato selection in yield improvement. It has also been said that he had in fact produced the wheat hybrids from which the first New Zealand bred variety, Cross 7 (5), was subsequently derived. In 1932 he had under observation 350 clones of cocksfoot, 200 of red clover, and 500 of perennial ryegrass. This work was on a part-time basis but a substantial attainment was the development and distribution of C.23, an improved pasture type cocksfoot (6) acclaimed at the time and subsequently certified for many years but in itself a step in the continued evolution until further selection at the Grasslands Division, DSIR produced the cocksfoot now in use.

"Working on Torchy's plots" became a catch-term in the life of generations of College students who in turn were allocated week about for this form of practical work. Their enthusiasm was derived from contact with the man himself. At this time, preceding the initiation of the Plant Research Bureau, DSIR, much was accomplished by Calder at the College on several issues of agronomic importance, the details of which have been preserved (7).

At the end of his first decade at Lincoln, he had become recognized as one of the country's most effective agronomists _ 1930s crops and pastures being regarded as the combined preserve of specialists so named. He published papers (8)-(15) of wide 
range and scope. He was also responsible, following Hilgendorf's persuasion, for organizing the multiplication on the College farm of pure seed for subsequent commercial use, from nucleus lines produced by units of the DSIR. At one stage this activity on the College farm involved 5 wheat varieties, 2 oat varieties, Italian and perennial ryegrass and partridge peas.

He had also aided the technique of ryegrass seed testing (16) and there was an intriguing development some years later during a period when there was urgency in providing Canterbury farmers with prompt reports on ryegrass seed given the pre-harvest examination for Blind seed (Gloeotinia temulenta) infection. Canterbury interests were emphatic that the seed testing service should be located in the main seed-producing district (Canterbury) and that the posting of ryegrass samples to Palmerston North was to be deplored. Calder and an associate had started helping their friends among local farmers by giving a pre-harvest ryegrass test

on an "answer while you wait" basis. They became quite heavily involved, testing scores of samples, which situation at least encouraged the Seed Testing Station administrators to announce they would establish a Ryegrass Testing Service for the duration of the growing season in Christchurch and Timaru. Calder and Co. were happy to vacate this field, satisfied that the desired local and prompt testing service was now available.

Although credit for the highly successful adaptation and utilization of subterranean clover on Canterbury light pasture land is rightly accorded to E. R. Hudson who organized his staff (17) to this end during the decade after 1936, this plant had been under report in Calder's earlier pasture plots. As a friend he had also collaborated with Hewlett and Neave (18) in the first successful use in New Zealand of sub-clover as a pasture plant.

Problems concerning fertilizer requirements and grazing management of this new pasture component on light dry land needed to be resolved and an 80 acre block was developed within a-comprehensive plan, with Calder directing and encouraging the collaboration of other colleagues. After an 8-year period he reported the results (19) on increases in production in terms of sheep liveweight increases, wool weight, carrying capacity and dry matter production. This work and its subsequent further interpretation appears to have been one of the College's greatest successes involving experimentation and the follow-up extension among farmers. 
It was at Ashley Dene also that he arranged in 1948 for the first field sowing in New Zealand of creeping lucerne derived from seed of Medicago glutinosa. The Crop Research Division, DSIR, through the instrumentality of the brother, Roy Calder, had brought this in from Canada in 1937 and had been testing it in single plant trials (20) for several years. Selection studies were made on the material at the College and with the continuing aid of research grants from DSIR, creeping lucerne for a time became predominant in the activity of Calder's department. The pioneer work culminated in the certification of College Glutinosa (21) as an acceptable pasture plant. Interest in the use of lucerne for grazing purposes, now widely practised, was substantially fostered by Calder and, as was his inclination, he sparked the process or trend, nurtured it, and encouraged others to carry on.

\section{HUMAN RELATIONSHIPS}

Consistently and through every year, he conducted lecture courses -diploma and degree. He was fortunate in being able to develop an intimate accord in the small or moderate sized classes of his times. He was held in the highest possible esteem - "Torchy" to all. He had taxing but pleasurable involvement with graduate students - those who aspired to follow a career in applied science and to this end had elected to produce a masterate thesis. Between 1935 and 1958, seventeen graduate students acknowledged him as their guide and supervisor (Appendix list) . They traversed material within the scope of plant pathology, pasture, lake shore and tussock ecology, plant physiology, plant breeding. These people are placed now in positions of authority within New Zealand and overseas.

He contributed to student instruction further by producing an Army Education and Welfare Service booklet (23) on cropping that was used extensively in rehabilitation courses for soldiers during and after World War 2. Later he also revised Hilgendorf's (24) durable practical book on weeds. In retirement he retained a link with students when he worked under the auspices of the College and the Ministry of Foreign Affairs as Supervisor of the practical work of African and Asian students. In this he used to the advantage of the students his widespread contacts and personal approbation among farmers throughout New Zealand.

At an early stage he learned to love the Canterbury natural environment, especially during legendary river raft, gold mining and climbing trips with the Hilgendorfs. Later, every opportunity 
was taken to go away on short or prolonged field trips with students where he gave instruction in ecology and encouraged the development of some of the country's most effective contemporary agricultural botanists. In his time students really learned to identify and to comprehend indigenous and introduced plants.

Posterity should conclude that J. W. Calder was in an elite company that included Riddet, McMeekan, Hilgendorf (others may be added by readers) who were inspirers of others, motivated to use their Science for Service. Working on useful things became natural to them.

Perennially youthful in appearance, he was ever genial and also a wise man, the personification of all that is regarded as good in character - "One of Nature's gentlemen". A most rare man, he was never known to speak ill or harshly of any other in public, nor to lose a unique poise, especially in tedious meetings where there was gross provocation on occasions. His spiritual fortitude was complete and he appeared to be unimpaired by being passed over twice by the College Council when they sought a new head of Lincoln College. Yet few could doubt that he would have graced the position, as indeed he did during the three periods when. called upon to deputize. Absolute honesty and integrity were hallmarks. Self-effacing and modest, he preferred to stand back and encourage others of stronger ambition or brash propensity, to move to the front.

"Torchy" (as his friends will ever call him) was a great allrounder. Various groups will honour their association with him as they recall: His University "Blue" in athletics and Canterbury provincial rugby player (1922) ; rugby coach of gentle persuasion among young men encouraged to play for the fun of it; country sub-union selector; for years the regular winner of the "Old Boys' race" at the Lincoln College sports - his name even to his age of maturity dominated the inscriptions on the trophy; President of the College's influential Old Students' Association; golfer, angler, bowler, craftsman woodworker, chess player, trooper with the wartime volunteer Independent Mounted Rifles; community man among both the Freemasons, Presbyterians and the village School Committee.

He liked being on farms and among farmers, and among that New Zealand-wide community, as well as among merchants and commercial people, he attracted the utmost esteem.

At the conclusion of his life it would have been comforting for him and his wife to contemplate that, within the close family circle, one son in Australia and a son-in-law in New Zealand had 
attained high responsibility in agricultural business organizations; that one son in the University of Melbourne was a basic scientist (plant physiology), and the other son-in-law, a professor of horticulture (Massey). The mantle on their shoulders should carry well and is appropriate to what they, like so many other intimates, got in inspiration from J. W. Calder.

I. D. BLAIR

\section{REFERENCES}

(1) Calder, J. W., 1927: Two New Zealand Wheats and their Mode of Inheritance. Canterbury University College M.Sc thesis (University of New Zealand).

(2) 1930: "Carpellody in wheat". Transactions of the N.Z. Institute, 61: 391.

(3) _ - (with L. Cockayne) 1932: Present vegetation of Arthurs Pass compared with that of 34 years ago. Journal of Ecology, 20; 271.

(4) - 1937: A cytological study of New Zealand species and varieties of Danthonia. Journal of the Linnean Society, 51: 1-9.

(5) Frankel, 0. H., 1934: Cross 7 Wheat. Bulletin No. 46, Department of Scientific and Industrial Research. $18 \mathrm{pp}$.

(6) Flay, A. H., 1930: N.Z. Joumal of Agriculture, 58: 515.

(7) Calder, J. W., 1928-1937: In "Half-yearly reports on research work at Canterbury Agricultural College". (Lincoln College Library.)

(8) 1933: Proceedings of the N.Z. Grassland Association, 2: 80.

(9) — 1934: ibid., 3: 65.

(10) - 1935: ibid., 4: 106.

(11) 1936: ibid., 5: 185

(12) Calder, J. W. (with F. W. Hilgendorf) 1923: N.Z. Joumal of Agriculture, 26: 354; ibid., 28: 400

(13) 1926: ibid., 33: 42.

(14) 1936: ibid., 53: 237

(15) 1936: ibid., 53: 146

(16) 1933: ibid., 47: 236

(17) Bevin, R. H., 1946: Land utilisation on Ashleydene farm Survey 1937-46. Lincoln College Technical Publication No. 1.48 pp.

(18) Hewlett, C. H.; Neave, A., 1937: N.Z. Journal of Agriculture, 51: 167.

(19) Calder, I. W., 1951: Investigations into the production of subterranean clover pastures on Ashleydene 1939-46. Lincoln College Technical Publication No. 6. 52 pp.

(20) Anon., 1942-46 inclusive: Annual reports, Department of Scientific and Industrial Research.

(21) Calder, J. W., 1957: The new grazing types of lucerne. Bulletin 334, Canterbury Chamber of Commerce.

(22) Calder, J. W.; Wardle, P., 1969: Succession in sub-alpine vegetation at Arthurs Pass New Zealand. N.Z. Ecology Society, 16: 36-47.

(23) Anon., 1943: Crops and Cropping. Army Education and Welfare Service. $133 \mathrm{pp}$.

(24) Hilgendorf, F. W., 1967: The Weeds of New Zealand, 7th ed. Whitcombe \& Tombs, Wellington. 261 pp. 


\section{APPENDIX}

\section{Postgraduates guided by J. W. Calder and their subsequent placement}

Campbell, D. A., M.Agr.Sc., 1930.

Red clover investigations.

Chief Soil Conservator, Ministry of Works.

Blair., 1. D., M.Agr.Sc., 1935.

Investigations of the foot-rot disease of wheat.

Reader in Agricultural Microbiology, Lincoln College.

Dick, R. D., M.Agr.Sc., 1938.

An ecological study and survey of the browntop-dominant grasslands of the Canterbury foothills with field studies of the establishment of subterranean clover on this area.

Chief Soil Conservator. North Canterburv Catchment Board.

Dakshindas, D. G., Ph.D.1 1957.

Studies on the physiology of germination of Cirsium arvense and the response of the plant to regulators. Academic position in India.

Dunbar, G. A., M.Agr.Sc., 1950.

Comparative studies of the germination of seed and the emergence and development of seedlings of some native and introduced plant species.

Agronomist, Tussock Grasslands and Mountain Lands Institute.

Esler, A. E., M.Agr.Sc., 1954..

Some aspects of competition between timothy and perennial ryegrass. Botany Division, DSIR, Auckland.

Evans, L. T., M.Agr.Sc., 1950.

The ecology of the Ellesmere Lake flats; a study of edaphic succession. Chief of the Bureau of Plant Industry, CSIRO, Australia.

FitzGERAld, J. N., M.Agr.Sc., 1949.

Investigation of the locality effect of seed wheat; yield studies on 81 lines of Cross 7 seed wheat.

Company manager, Wellington.

Forbes, I. G., M.Agr.Sc., 1951.

Methods of evaluation in a variety trial of cabbage.

Assistant Director (Horticulture), Department of Agriculture, Wellington.

Harrow, K. M., M.Agr.Sc., 1938.

An investigation of pre- and post-emergence rots of peas.

Scientist, Plant Diseases Division, DSIR, Auckland.

LyalL, J. S., M.Agr.Sc., 1951.

Seasonal variation in the cyanogenetic glucoside content of wheat clover.

Farming, Temuka, South Canterbury.

Malcolm, J. P., M.Agr.Sc., 1947.

An ecological study of the barley crop in New Zealand.

Canterbury (N.Z.) Malting Co., Christchurch.

Moffat, R. W., M.Agr.Sc., 1957.

Ecological studies on montane tussock grassland.

Ivon Watkins-Dow Ltd, New Plymouth.

PAlmer, T. P., M.Agr.Sc., 1947.

Population studies in' a Triticum cross.

Plant breeder, Crop Research Division, DSIR, Lincoln, 
Sewell, T. G., M.Agr.Sc., 1948.

Study of montane tussock grassland with reference to growth, seeding and behaviour of the principal species.

Department of Agriculture, Levin.

Tauneed Mohammed, M.Agr.Sc., 1948.

The influence of weather on the yield of wheat in New Zealand.

Government position, India.

WKaIGHT, M. J., M.Agr.Sc. 1957.

The ecology of Lake Ellesmere spit.

Fruit Research Station, DSIR. 